\title{
RURAL TOURISM IN ROMANIA AND ADOPTING BEST PRACTICES FROM OTHER STATES
}

\section{TURISMO RURAL EN RUMANÍA Y ADOPCIÓN DE LAS MEJORES PRÁCTICAS DE OTROS ESTADOS}

\author{
Răbonțu Cecilia-Irina \\ Babucea Ana-Gabriela \\ Bălăcescu Aniela
}

"Constantin Brâncuși" University of Târgu Jiu, Romania mcecilia.rabontu@gmail.com

Material original autorizado para su primera publicación en la revista académica REDMARKA. Revista Digital de Marketing Aplicado.

https://doi.org/10.17979/redma.2017.01.018.4856

Recibido: 17 Febrero 2017

Aceptado: 5 Junio 2017

\section{Abstract}

Tourism is one of the important pillars of many national economies. Practicing the tourism has a multiplier effect on several industries, being interdependent with the food industry, communications, transport industry etc.

Worldwide, all rural areas face the same problems: economic decline, environmental degradation, poverty of population or gradual loss of national identity. Its population is aged, young people preferring to migrate to cities. In this context, the villages are struggling to maintain its viability. 
Tourism is one of the sectors that can contribute to resuscitate villages. Practicing rural tourism was developed in response to human needs, subjected to daily increasing stress, to recreate the economic needs of these areas and the concern to preserve the environment and tradition.

This paper aims to analyze the trends and changes rural tourism in Romania, namely how tourism activity has evolved, but the direction he is going, too. For this, we will use the existing data and studies.

Studying this theme is justified by the actuality of the topic, given that attempts to maximize the benefits from tourism in a way that nature and heritage anthropogenic authentic to not suffer, but also the need to develop the localities and rural areas where only tourism and agriculture are productive domains. Rural tourism is a viable alternative in a society preoccupied with sustainable development which is moving increasingly towards forms of ecotourism. In addition to protecting nature, heritage conservation and preservation of tradition and stimulating the authenticity of the village, rural tourism brings the socio-economic benefits for the local population.

Rural tourism can meet tourist needs without harming the environment. It appears as a suitable alternative for the daily man increasingly stressed and pressured economic and social. Rural tourism is a "strategy" viable recovery of the villages, from several points of view: attracting earnings in areas where it is practiced; generating employment; contributing to the development of rural areas; supporting the rejuvenating of villages population; preserving and protecting the natural environment; keeping alive tradition; meeting the needs of tourists.

Tourism in general and in rural areas, in particular, is a springboard for other industries in that area, but also for society. Practicing this activity in rural areas can lead to economic development, but also to raising living standards and quality of life. Facing the challenges of globalization and with uncertain economic conditions, rural tourism can be a "lifeline", under proper capitalization and promotion of effective heritage 
After identification the best practices in rural tourism that held in other countries, we propose for adopting those practices which are fit for rural tourism in Romania.

Development of rural tourism in recent years is not accidental. The village and the tradition create a competitive tourism product, bidder. Rural tourism is based on everything that is specific national identity, but also everything that involves cultural and human environment.

Romania resourced rural tourism that involves a variety of activities. Given that they would be exploited properly, Romanian tourism could attract large numbers of visitors, tourists from all socio-economic and professional categories, and satisfying their preferences accordingly. 


\section{The situation of the rural tourism in Romania}

Rural areas of Romania presents a social and economic situation quite difficult, aspect rendered by the following elements:

- incomes are with $20-30 \%$ lower than those in the cities;

- local administrations do not have sufficient resources to combat problems encountered in villages;

- $75 \%$ of the rural inhabitants living in poverty, aspect supported by statistical data according to which $87.1 \%$ of Romania's surface is represented by the rural area where live approximately $45 \%$ of Romanians;

- according to NIS ${ }^{1}$, employment opportunities in rural areas are close to zero.

Therefore, it is justified the lifting of tourism at the pylon of socioeconomic restarting of rural areas. It benefits from a strong and numerous promotional support and development policies through legislative measures which granting advantages to those who performing the rural touristic activities.

To analyze the situation of rural tourism in Romania, we will use statistical data related to this activity, offered by official statistical sources. We will discuss issues related to number of Establishments of touristic reception at nationwide, the accommodation capacity, the number of tourists accommodated, etc. in an attempt to identify the situation of rural tourism in Romania.

\section{Table no 1. The number of establishments of touristic reception at national level}

\footnotetext{
${ }^{1}$ INS-România în cifre, 2011

REDMARKA UIMA-Universidad de A Coruña - CIECID

Año X, Número 18, (2017), v I pp. 5-18

http://www.redmarka.net/ ISSN 1852-2300
} 


\begin{tabular}{|c|c|c|c|c|}
\hline & 2012 & 2013 & 2014 & 2015 \\
\hline TOTAL & 5821 & 6009 & 6130 & 6821 \\
\hline Hotels & 1400 & 1445 & 1473 & 1545 \\
\hline Motels & 206 & 215 & 212 & 221 \\
\hline Tourist Inns & 3 & 3 & 5 & 3 \\
\hline Hostel & 178 & 185 & 204 & 248 \\
\hline Touristic villas & 621 & 621 & 624 & 643 \\
\hline Bungalows & 242 & 249 & 242 & 280 \\
\hline Tourist chalets & 146 & 152 & 162 & 196 \\
\hline Holiday villages & 6 & 6 & 9 & 7 \\
\hline Campings & 48 & 48 & 52 & 66 \\
\hline Camps for students & 70 & 62 & 62 & 63 \\
\hline Touristic halting places & 39 & 35 & 35 & 33 \\
\hline Guesthouses & 1247 & 1335 & 1323 & 1527 \\
\hline $\begin{array}{l}\text { Agro-touristic } \\
\text { houses }\end{array}$ & 1569 & 1598 & 1665 & 1981 \\
\hline Tourist cottages & 36 & 45 & 53 & 61 \\
\hline $\begin{array}{l}\text { Ships } \\
\text { spaces }\end{array}$ & 10 & 10 & 9 & 10 \\
\hline
\end{tabular}

Source: Romanian Statistical Yearbook, 2015 and Romania's tourism Statistical Breviary, 2016

The number of establishments of touristic reception presents an upward trend, overall in 2014 was by $5.3 \%$ more than in 2012, while on types of accommodation establishments in most cases are recorded increases except for school camps, Touristic halting places and spaces accommodation vessels. In 2015 situation is extremely favorable for the number of establishments, increasing is very high: $11.3 \%$ compared to 2014 and $17.5 \%$ compared to 2012

Regarding the number of agro-touristic boarding houses, in which practice rural tourism, we find that in 2013 their number increased by 29 compared to 2012 year, while in 2014 their number was 67 higher than the 2012 year and with 96 to 2013 year. In 2015, according to data from the Romania's tourism - Statistical Breviary, agro-touristic boarding houses took an important elan, being about 300 units more, something that can translate into greater interest of entrepreneurs for such a deal that could be developed on European funds but and in demand increasingly higher for rural tourism. 
Also, in rural areas it is located and a large part of tourist cottages, touristic boarding houses, touristic halting places, camping, camps, holiday villages, villas, cottages, inns, motels and even hotels, but statistical data are not reporting on the residence of those establishments.

Even if numerically, establishments are more numerous it is important to analyze and accommodation capacity which is given by the number of places.

Table 2. The existing touristic accommodation capacity -number of places

\begin{tabular}{|l|r|r|r|r|}
\hline & \multicolumn{1}{c|}{$\mathbf{2 0 1 2}$} & \multicolumn{1}{c|}{$\mathbf{2 0 1 3}$} & \multicolumn{1}{c|}{$\mathbf{2 0 1 4}$} & \multicolumn{1}{c|}{$\mathbf{2 0 1 5}$} \\
\hline TOTAL & 301109 & 305707 & 311288 & 328313 \\
\hline Hotels & 181702 & 183330 & 186236 & 190275 \\
\hline Motels & 8078 & 8493 & 7883 & 8331 \\
\hline Touristic inns & 81 & 61 & 143 & 63 \\
\hline Hostels & 7562 & 8482 & 9116 & 11757 \\
\hline Touristic villas & 14775 & 14047 & 13812 & 14473 \\
\hline Bungalows & 2663 & 2834 & 2722 & 2768 \\
\hline Touristic chalets & 5150 & 5183 & 5128 & 5876 \\
\hline Holiday villages & 352 & 372 & 717 & 557 \\
\hline Campings & 12816 & 11945 & 12925 & 15039 \\
\hline School camps & 10908 & 9851 & 9759 & 7979 \\
\hline Touristic halting places & 1847 & 1800 & 2209 & 1792 \\
\hline Touristic boarding houses & 25019 & 27325 & 27295 & 32051 \\
\hline $\begin{array}{l}\text { Agro-touristic } \\
\text { houses }\end{array}$ & 27453 & 28775 & 30480 & 35188 \\
\hline Tourist cottages & 2199 & 2665 & 2398 & 2657 \\
\hline $\begin{array}{l}\text { Ships accommodation } \\
\text { spaces }\end{array}$ & 504 & 517 & 465 & 507 \\
\hline
\end{tabular}

Source: Statistical Yearbook of Romania,2015 and Romania's tourism -

Statistical Breviary, 2016

Also, the number of accommodation places was increasing in the period under review, 2015 was the best year compared to 2014 which recorded a growth of $5.4 \%$. The number of accommodation places in agro-touristic boarding houses increased by $11.02 \%$, something which brings to the fore the REDMARKA UIMA-Universidad de A Coruña - CIECID

Año X, Número 18, (2017), v I pp. 5-18

http://www.redmarka.net/ ISSN 1852-2300 
growing interest of investors and entrepreneurs in developing establishments of touristic reception in rural areas, of course correlated with the demand for rural tourism. To analyze the demand for tourism in general but in particular for rural tourism we present data on the number of tourists.

Table 3. Number of tourists in the establishments of touristic reception, by types of units

\begin{tabular}{|l|c|c|c|c|}
\hline & $\mathbf{2 0 1 2}$ & $\mathbf{2 0 1 3}$ & $\mathbf{2 0 1 4}$ & $\mathbf{2 0 1 5}$ \\
\hline TOTAL & $\mathbf{7 6 8 6 4 8 9}$ & $\mathbf{7 9 4 3 1 5 3}$ & 8465909 & 9930496 \\
\hline Hotels & 5779858 & 5917889 & 6326198 & 7282484 \\
\hline Motels & 230835 & 242522 & 231740 & 259961 \\
\hline Touristic inns & 832 & 643 & 1336 & 1994 \\
\hline Hostels & 153759 & 147848 & 189243 & 258106 \\
\hline Touristic villas & 240961 & 24287 & 231312 & 291540 \\
\hline Bungalows & 16780 & 16393 & 18062 & 24491 \\
\hline Touristic chalets & 86322 & 94888 & 94049 & 94976 \\
\hline Holiday villages & 3547 & 5810 & 3348 & 5932 \\
\hline Campings & 62516 & 42879 & 30673 & 60723 \\
\hline School camps & 51539 & 48177 & 59523 & 48109 \\
\hline Touristic halting places & 12113 & 12987 & 14482 & 17772 \\
\hline Touristic boarding houses & 586119 & 653467 & 704129 & 899494 \\
\hline $\begin{array}{l}\text { Agro-touristic boarding } \\
\text { houses }\end{array}$ & 447113 & 501746 & 549302 & 672756 \\
\hline Tourist cottages & 6927 & 9580 & 12013 & 11798 \\
\hline
\end{tabular}

Source: Processing of data from Statistical Yearbook of Romania, 2015

In terms of the number of tourists in the establishments of touristic reception in the period 2012-2015, there is a positive trend, in the sense that, from year to year, more tourists were registered accommodated. So, in 2013 the overall number of tourists has increased by 3.3\% compared to 2012 and in 2014 increased by $6.5 \%$ compared to 2013. In 2015 compared to 2014 the growth was by $17 \%$. Number of tourists in touristic boarding houses and agrotouristic boarding houses has evolved in the same direction, registering significant increases that support the assertion that the demand for rural tourism in Romania is increased. It is very important to analyze the origin of domestic and foreign tourists, in this regard presenting the following data:

\footnotetext{
REDMARKA UIMA-Universidad de A Coruña - CIECID

Año X, Número 18, (2017), v I pp. 5-18

http://www.redmarka.net/ ISSN 1852-2300
} 
Table 4. The number of domestic and foreign tourists

\begin{tabular}{|c|c|c|c|c|c|c|}
\hline & \multicolumn{3}{|c|}{ Domestic tourists } & \multicolumn{3}{|c|}{ Foreign tourists } \\
\hline & 2012 & 2013 & 2014 & 2012 & 2013 & 2014 \\
\hline TOTAL & $\begin{array}{l}603005 \\
3\end{array}$ & $\begin{array}{c}622579 \\
8\end{array}$ & $\begin{array}{c}655133 \\
9\end{array}$ & $\begin{array}{c}165643 \\
6\end{array}$ & $\begin{array}{c}171735 \\
5\end{array}$ & $\begin{array}{c}191457 \\
0\end{array}$ \\
\hline Hotels & $\begin{array}{c}429326 \\
3\end{array}$ & $\begin{array}{c}438042 \\
9\end{array}$ & $\begin{array}{c}459986 \\
1\end{array}$ & $\begin{array}{c}148659 \\
5\end{array}$ & $\begin{array}{c}153746 \\
0\end{array}$ & $\begin{array}{c}172630 \\
7\end{array}$ \\
\hline Motels & 215615 & 226604 & 216068 & 15220 & 15918 & 15672 \\
\hline Touristic inns & 818 & 643 & 1336 & 5 & & \\
\hline Hostels & 133886 & 128159 & 162738 & 19873 & 19689 & 26505 \\
\hline Touristic villas & 219780 & 220903 & 207354 & 21181 & 21284 & 23958 \\
\hline Bungalows & 15261 & 15439 & 17312 & 1519 & 954 & 750 \\
\hline Touristic chalets & 80407 & 89497 & 88711 & 5915 & 5391 & 5338 \\
\hline Holiday villages & 3273 & 5439 & 3179 & 274 & 371 & 169 \\
\hline Campings & 51204 & 35032 & 26827 & 11312 & 7847 & 3936 \\
\hline School camps & 51183 & 47822 & 58774 & 356 & 295 & 749 \\
\hline $\begin{array}{ll}\text { Touristic } & \text { halting } \\
\text { places } & \end{array}$ & 11709 & 12442 & 13935 & 404 & 545 & 547 \\
\hline $\begin{array}{l}\text { Touristic boarding } \\
\text { houses }\end{array}$ & 529236 & 590069 & 635182 & 56883 & 63395 & 68947 \\
\hline $\begin{array}{l}\text { Agro-touristic } \\
\text { boarding houses }\end{array}$ & 416939 & 463563 & 507868 & 30174 & 38183 & 41434 \\
\hline Tourist cottages & 6801 & 9179 & 11789 & 126 & 401 & 224 \\
\hline $\begin{array}{l}\text { Ships } \\
\text { accommodation } \\
\text { spaces }\end{array}$ & 678 & 578 & 375 & 6599 & 5662 & 34 \\
\hline
\end{tabular}

Source: Processing of data from Statistical Yearbook of Romania, 2015

From data for Table 4, we concluded that, same as at national level and rural tourism has increased both the number of Romanian tourists and the number of foreign tourists. Compared to 2012, in 2014 was with $22.85 \%$ more tourists in agro-touristic boarding houses, the number of Romanian tourists increased by $21.8 \%$ and the number of international visitors with $37.31 \%$. From these data, we can say that in Romania, rural tourism is on the rise, with 
opportunities to develop increasingly, in the presence of a competitive rural tourism product.

\section{Rural tourism in other countries}

In Europe, the rural tourism is recognized in many countries such as France, Denmark, Italy, Austria, Spain, etc. In trying to find the best practices that agro-touristic boarding houses from other states to practice them, present some specificities in the most important countries that had suscces with rural tourism.

France is considered to be the cradle of tourism in rural areas, due to old tradition, and maximum rates of diversification, organization and promotion which it realize. Most of the French equipment can be called rustic houses and controlled, approved and reserved by National Federation "Gites de France" (founded in 1955), which includes over 38,000 owners, over 55,000 equipment accommodation, 600 employees, 95 regional departments. Each year, this association conducted numerous promotional materials more than 2 million guides (11 national guidelines, 95 departments, a journal of the owners and creators a guide). If we consider the statistics we find that France ranks first in the number of equipment accommodation in rural areas - 65303 hostels.

What attracts towards rural tourism in France is French cuisine; white, red, pink or black wines,; champagne; french-cancan; cheese, their way of being: undisciplined, seductive, a little chauvinistic, but especially attentive hosts, ready to satisfy any visitors, but also quality price ratio which is a major concern for each provider. To those so far is necessary to add a strong attachment for native region and some aversion to change one region to another and take care of the authorities to support these companies through loans (agricultural, hotel special arrangement of villages) for long-term (up to 15 years) and low-interest (3-5\%). All these and a few things that you can not 
discover only than the spot contributed to the new look of French tourism in rural areas and its ranking in the top of the preferences of tourists everywhere. ${ }^{2}$

Italy is another country which has a recognized rural tourism, is famous for manifestations "green holidays" and its main component agrotourism. In Italy is an association involved, namely L'Asociazione Nazionale per l'Agriturismo, I'Ambiente e Territorio which was founded in Rome in 1965, which publishes regularly The guide of rural hospitality which containing information on farm holidays addresses, descriptions machinery, equipment, etc. typical, about facilities in 20 regions of Italy. In this country there are specific rural tourism equipment and we refer to farms, ancient renovated housing, pensions, rest houses, modern villas, traditional houses, castles and fortifications.

Which attracts tourism in rural areas of Italy refers to diversity of cultural traditions and landscapes, culinary traditions of Italian cuisine; famous wines; folklore dances and songs and art music; various architectural monuments; poetry and legend settlements in each placement. Famous regions are are famous regions, Piemonte, Lombardia, Trentino, Veneto, Emilia Romagna, Liguria, Toscana, Lazio, Abruzzo, Umbria, Campania, Puglia, Calabria, Sicilia and not least Alto Adige.

Austria is the country of mountain glaciers and crystalline lakes. This rural tourism activity date back more than 150 years, when tourist accommodation is either in rustic guesthouse or touristic inns. Today appeared two notions: "the tourist village of recreation," and "rest resort". The rural area is represented by cities and villages have fewer than 10,000 inhabitants. Rural tourism contents: tourism la ferme-> most practiced; the farm with specific: organic foods with traditional kitchen, children's farms, farms for riding, wine farms, farms for people with disabilities and other programs; vacations with specific in nature: hiking, ecotourism, mountaineering, riding, fishing, adventure sports, educational, tourism, travel, art, ethnic tourism. ${ }^{3}$

\footnotetext{
${ }^{2}$ http://www.agriculturae.ro/index.php/zone-turistice/strainatate/1053-franta-leaganul-turismului-rural.html ${ }^{3}$ https://www.academia.edu/6223681/Turismul_rural_in_Austria REDMARKA UIMA-Universidad de A Coruña - CIECID

Año X, Número 18, (2017), v I pp. 5-18 http://www.redmarka.net/ ISSN 1852-2300
} 
Spain and Portugal, two countries of the Iberian Peninsula, represent important destinations in Europe for tourists who prefer rural tourism, despite the fact that coastal tourism prevails in the tourism industry of these countries. Spain, the second tourist destination after France, is a large pool receiver tourism demand areas, "white villages" in Andaluzía, in the south of country, music and flamenco dance, bulfighting and the numerous locations of traditional accommodation constitutes attractions for visitors. Rural accommodation on Spanish territory is ensured by halting rural, equestrian farms, farm-inn, guest room-grouped in associations Agroturism Basc and Spa Agroturism, historic buildings, ex. PARADORS - is a chain of hotels founded during the Franco dictatorship as a way of financing the reconstruction, but also in order to save historic buildings that have been renovated and converted into comfortable rural hotels. Participation in free trade zones in rural tourism is fundamental to establish business contacts and to know the competing products, and Spain is a country where many fairs are conducted in rural tourism. ${ }^{4}$

\section{Conclusions}

Rural tourism is a viable solution for the problems which rural areas confront, and can contribute to resuscitate villages. Rural tourism is an important direction for action in all strategies of tourism development. As we have demonstrated, Romanian village has a tourism potential internationally. The recommendations for development of rural tourism aimed at both business diversification and valorisation of creative potential and attention to each customer segment and a system of effective promotion.

The mutations from rural tourism have emerged as a result of changes in the demand for rural tourism. Analysis of consumer trends and motivations of rural tourism consumer underlying aspects of its development, such as urban

\footnotetext{
${ }^{4}$ http://www.utgjiu.ro/revista/ec/pdf/2007-01/47_Stoian\%20Mihaela.pdf REDMARKA UIMA-Universidad de A Coruña - CIECID Año X, Número 18, (2017), v I pp. 5-18 http://www.redmarka.net/ ISSN 1852-2300
} 
stress, better education, leisure developments, the level of costs, infrastructure development, health concerns.

Rural tourism corresponds with the principles of sustainable development. This makes them more attractive, in the context where tourists tend to make eco-friendly choices.

At national level, rural tourism enjoys a fairly weak promotion. However, there are numerous policies to support. As a result, the number of tourists in rural areas has increased by about a third in recent years.

Conclusions of this paper are:

- Romania has a significant rural and varied tourism potential;

- Rural tourism potential is insufficiently exploited;

- Require concrete measures for the recovery of tourism in rural areas;

- Investment is needed in road infrastructure and accommodation, but also investments related to staff training;

- Rural tourism involves specific activities and other forms of tourism, for which there are significant resources in the Romanian village: ecotourism, mountain tourism, caving, cycling tourism, business tourism, agritourism, rest and recreation;

- Tourism products need customized by categories of tourists.

Proposals aimed the increase of competitiveness of the Romanian village tourism are:

- Capitalization of resouces by categories, namely: caving resources, sports resources, ethnographic resources, cultural resources, ecological resources, historic resources, agro-resources etc .;

- Rehabilitation of buildings and monuments;

- Improvement of road infrastructure;

- Training and qualification of human resource;

- Elaboration of a strategy to promote rural tourism;

- Crearea unui brand turistic din satul romanesc; 
- Creating a brand of Romanian village;

- Emphasizing the elements that define each rural area;

- Development of tourist information centres;

- Supporting events and investment in rural areas.

From the analysis of the specific rural tourism from presented countries is noted that the units involved in this activity are grouped into associations and it promotes constant through well-designed promotional materials. Those associations are involved in order to establish common objectives for rural tourism stakeholders in each area and attractions with their specifics.

Proposals for rural tourism development focuses on creating customized travel. They should meet the needs of tourists and their concerns. These rural tourism products could be made up through investments and through responsible tourism offer, valuing natural and anthropogenic targets, enhanced activities constituting themselves a tourist motivation.

\section{References}

1. Andreiana, V., Stoica C., Strategic Marketing alternatives at agrotourism guest house level, 2013, publicat pe www.ceeol.com

2. Bâc, D., Turismul și dezvoltarea durabilă: realități, provocări și oportunități, Oradea, 2012

3. Istrate I., Bran F., Roșu A., Economia turismului și mediul înconjurător, Editura Economică, 1996

4. Mazilu, M., Turismul - o relație privilegiată cu dezvoltarea durabilă, Revista de Marketing Online, Volumul 1, Numărul 4

5. Niculescu, G., Răbonțu, I.C., Marketing turistic, Ed. Academica Brâncuși, Târgu Jiu, 2006

REDMARKA UIMA-Universidad de A Coruña - CIECID

Año X, Número 18, (2017), v I pp. 5-18

http://www.redmarka.net/ISSN 1852-2300 
6. Petrea R.,Petrea,D., Turism rural, Editura Presa Universitară Clujeană, ClujNapoca, 2000

7. Răbonţu, I.C., Vasilescu M., The evaluation of Romanian Tourism in terms of economic instability, Annals of the „Constantin Brâncuși” University of Târgu Jiu, Economy Serioes, Vol. 2/2012, Editura Academica Brâncuși

8. Răbonțu, I.C., Bălăcescu A., The study of travelling demands of Romanian residents, International Journal of Business, Management and Social Sciences, Vol. 2, Nr. 3, 2011, pag. 20-28

9. Academia Română, Strategia de dezvoltare durabilă pe termen mediu și lung a agriculturii și a spațiului rural din România, material publicat pe http://www.undp.ro/download/files/sndd/SNDD RO 176x235.pdf

10. Carta Europeană a Spațiului rural, http://lege5.ro/Gratuit/g4zdmmrw/ordinulnr-143-2005-privind-definirea-si-caracterizarea-spatiului-rural

11. Breviar Statistic Turismul României, 2015, București

12. http://www.agriculturae.ro/index.php/zone-turistice/strainatate/1053-frantaleaganul-turismului-rural.html

13. https://www.academia.edu/6223681/Turismul_rural_in_Austria

14. http://www.utgjiu.ro/revista/ec/pdf/2007-01/47 Stoian\%20Mihaela.pdf

15. Anuarul Statistic al României, 2015 